(c) American Dairy Science Association, 2003.

\title{
Timeliness and Effectiveness of Progeny Testing Through Artificial Insemination
}

\author{
H. D. Norman, ${ }^{*}$ R. L. Powell, ${ }^{*}$ J. R. Wright, ${ }^{*}$ and C. G. Sattlert ${ }^{1}$ \\ *Animal Improvement Programs Laboratory, Agricultural Research Service, USDA, Beltsville, MD 20705-2350 \\ †National Association of Animal Breeders, Columbia, MO 66205-1033
}

\begin{abstract}
Progeny-test (PT) programs of US artificial-insemination (AI) organizations were examined to determine timeliness of sampling, PT daughter distribution, rate of return of PT bulls to widespread service, and genetic merit of PT bulls compared with AI-proven and natural-service (NS) bulls. Bull age at semen release and at birth and calving of PT daughters was documented by breed (Ayrshire, Brown Swiss, Guernsey, Holstein, Jersey, and Milking Shorthorn) for bulls that entered AI service since 1960. Mean Holstein bull age at semen release (16 mo) changed little over time, but standard deviations (SD) decreased from 4.0 mo during the 1960 s to 2.4 mo during the 1990 s. Most Holstein bulls (80\%) had semen released by 18 mo. Mean age of Holstein bulls at birth and calving of PT daughters during the 1990s was 29 and 56 mo, respectively (a decline of 4 mo from the 1960s); SD decreased from 6 to 3 mo. Bulls of other breeds usually were older at birth and calving of PT daughters, and SD were larger. Mean Holstein bull age when $80 \%$ of PT daughters had been born declined from 36 mo during the 1960 s to 31 mo during the early 1990s; for other breeds, bulls showed the same trend but at older ages. Mean Holstein bull age when $80 \%$ of PT daughters had calved declined from 65 mo during the 1960 s to 59 mo during the 1990s; for other breeds, bulls were older. Percentage of herds with PT daughters has increased over time. For Holsteins, herds with five or more usable firstparity records that had PT daughters with usable records increased from 15\% during 1965 to $61 \%$ during 1998; percentage of herds with from 1 to $19 \%$ PT records increased from 11 to $38 \%$, and percentage of herds with $>50 \%$ PT daughters increased from 1 to $5 \%$. Percentage of Holstein PT bulls returned to AI service declined to about $12 \%$ for bulls with PT entry

Received December 31, 2001

Accepted October 15, 2002.

Corresponding author: H. D. Norman; e-mail: dnorman@aipl. arsusda.gov.

${ }^{1}$ Current address: Select Sires, Inc., 11740 US 42N, Plain City, $\mathrm{OH}$ 43064-0143.
\end{abstract}

around 1990; for other breeds, 12 to $23 \%$ of most recent PT bulls were returned to service. Percentage of milking daughters that had records usable for genetic evaluation that were sired by PT bulls increased steadily from 10 to $18 \%$, whereas percentage of daughters with usable records that were sired by NS bulls declined from 14 to 7\%. Milk yield of daughters of AI-proven bulls was 107 to $200 \mathrm{~kg}$ greater than for daughters of PT bulls and 366 to $444 \mathrm{~kg}$ greater than for daughters of NS bulls for all years. More extensive and rapid sampling and increased selection intensity of PT programs have led to more rapid genetic progress. More extensive use of AI could increase US producer income by millions of dollars annually.

(Key words: artificial insemination, progeny test, selection intensity, sire sampling)

Abbreviation key: AIPL = Animal Improvement Programs Laboratory, $\mathbf{N S}=$ natural service, $\mathbf{P T}=$ progeny test.

\section{INTRODUCTION}

Progeny testing is conducted to obtain an evaluation of genetic merit of individual animals based on performance of offspring. A number of different methods for increasing the rate of genetic improvement of dairy cattle have been proposed since traditional progenytest (PT) methods became practiced routinely. Where large-scale recording is lacking, use of a nucleus test herd has been recommended (Hinks, 1978; Smith, 1988). Alternative strategies have been suggested that incorporate multiple ovulation and embryo transfer (Nicholas and Smith, 1983) to produce offspring to augment a traditional PT program. Despite the abundance of current research in genetic markers, genetic improvement for dairy cattle is still dependent primarily on a successful AI PT program.

Several factors have an impact on PT effectiveness and rate of genetic improvement. Genetic merit of PT bulls returned to AI service is largely determined by number of PT bulls sampled, PT accuracy, and intensity of culling based on initial PT evaluations. Previous papers (Miller, 1981; Norman and Powell, 1986, 1992, 
1999) have reported the number of young bulls entering AI PT programs in the United States. Recently, Norman et al. (2001) documented several aspects of PT programs across time, including number of PT bulls sampled and mean numbers of PT daughters and herds in the evaluation. They also reported ages of ancestors when PT bulls were born and registration status and location of PT daughters by US state.

To minimize generation interval, PT programs must ensure that bulls are sampled and evaluated at a young age. Young bulls with outstanding pedigree merit should have semen collected as soon as maturity allows and semen distributed and used quickly in herds enrolled in milk recording, thus increasing the likelihood that daughters are born and calve when bulls are relatively young. Such a strategy requires an intensive effort by AI organizations followed by considerable cooperation by dairy producers. Operational characteristics of PT programs, such as rapidity of sampling, have an impact on program success. Although those characteristics can help assess effectiveness of AI organization programs, they have seldom been documented.

Whether PT bulls are genetically superior or inferior to AI-proven bulls available at the same time depends partly on intensity of selection for both groups. Genetic comparison of AI bulls with natural service (NS) bulls also is affected by selection intensity. Historically, high pedigree merit of bulls that enter AI PT programs has given an advantage to both PT and AI-proven bulls over NS bulls. McDaniel and King (1974) and King and McDaniel (1974) showed that AI-sired registered and grade daughters were 34 to $191 \mathrm{~kg}$ superior to NS-sired daughters depending on breed. Superiority of AI-sired daughters was generally greatest for firstparity animals but declined with advancing age, probably primarily because of more intense culling of NS daughters. Powell and Norman (1989) reported AI sires were $211 \mathrm{~kg}$ superior to non-AI sires for predicted difference for milk and $292 \mathrm{~kg}$ higher when accounting for more extensive marketing and greater numbers of daughters for top ranking bulls. Mean PTA for traits evaluated for those groups of bulls are provided by the Animal Improvement Programs Laboratory (AIPL, 2001), USDA (Beltsville, MD), but without weighting for differential use; NS bulls are consistently inferior to the two AI groups. Other studies have focused primarily on genetic difference between PT and AI-proven bulls. Powell and Norman (1989) reported that sires in AI sampling were of essentially equal merit to active AI sires, which suggests they would average near percentile 50, but active AI sires were higher by $108 \mathrm{~kg}$ if differential usage was considered. Meinert et al. (1992) estimated that daughters of PT bulls were superior in yield to daughters of AI-proven bulls in PT herds of one AI organization. McDaniel and Bell (1992) and Abdullah and McDaniel (2002) reported highly selected PT bulls were nearly of equal merit to intensively selected AI-proven bulls. Weigel et al. (1995) reported that PT bulls ranked at percentile 57 of AIproven bulls; however, the mean percentile was decreasing annually by 0.9 . That decrease could have resulted from the recent increase in number of PT bulls sampled each year, which would have permitted more intense selection in choosing AI-proven bulls or reduced selection intensity in young bulls. A reexamination of genetic merit expected from use of PT, AIproven, and NS bulls would benefit producers and financial institutions that provide loans to producers in making economic decisions.

A few studies have compared genetic evaluations of bulls sampled through NS or syndicate sampling and later marketed through AI with bulls sampled initially through AI PT. Norman et al. (1985) found no bias between AI- and NS-sampled bulls throughout the 1970s when comparing a bull's last evaluation before entering AI with his last available evaluation. Meinert and Pearson (1992) studied consecutive first- and second-crop evaluations for both AI- and non-AI sampled bulls. They reported that first-crop evaluations after the initial evaluation of non-AI sampled bulls tended to be overestimated. They also reported that bias in favor of non-AI sampled bulls had increased over time.

Because dairy producers initiated breeding their own cows with semen purchased directly from AI organizations, records that indicate extent of AI use and proportion of the matings to $\mathrm{PT}, \mathrm{AI}-$ proven, and NS bulls have not been available. Norman and Powell (1992) estimated percentage of cows bred through AI after 1971 by using information from technician reports and domestic semen sold for the same year and extrapolating to later years when technician reports were no longer available. Unfortunately, determination of the accuracy of their estimates was impossible. Knowledge of the proportion of services to bulls in each AI-status category during the insemination period would be helpful as would information on the proportion of services from each category that resulted in calves. Those statistics could be provided if calf data were available, but the national dairy database at AIPL contains little information on grade calves. Because information on insemination and progeny birth is usually not available for individual bulls, a summary derived from cows in milk is the most accessible information for examining changes in $\mathrm{AI}$ contribution across time.

A primary objective of this study was to examine intermediate steps of AI PT programs related to timeli- 
ness of obtaining genetic evaluations and to determine how quickly each operational step was being executed. Means and standard deviations of age of PT bulls when semen was released and when their daughters were born and calved are indicators of efficiency of progeny testing across time. This study was undertaken to document frequency and timeliness of sampling within herds with various percentages of PT use. The relationship of genetic merit for yield with season of semen release was also examined. Other objectives were to determine intensity of selection after the first genetic evaluation of a PT bull is available, examine changes in AI contribution across time, and compare genetic merit of PT, AI-proven, and NS bulls available at the same time.

\section{MATERIALS AND METHODS}

Data were obtained from the national dairy database at AIPL, which contains information from several sources and, thus, facilitated an examination of characteristics of the AI program. Artificial-insemination organizations supplied information on bulls entering PT programs and date semen was initially released. Dairy Herd Improvement affiliates provided milk yield and component information used to calculate lactation records. Breed associations and dairy records processing centers provided animal identification and pedigree information.

To restrict data to first-crop PT daughters, only cows born between 8 and 42 mo after sire entry into AI were considered to be PT daughters. A few young bulls had semen marketed continuously without restriction on number of sampling units shipped to the field. Therefore, only the first 125 daughters with information included in their sire's genetic evaluation as determined by calving date were considered to be PT daughters. For information on a PT daughter to be included, a first-parity record usable for USDA-DHIA genetic evaluation was required. If a daughter changed herds, herd designation was the one that produced the usable record from first parity.

Bulls were designated as AI PT if they had a sampling controller code from the National Association of Animal Breeders (2001), entered PT service between 10 and 29 mo of age, and were owned by an AI organization located in the United States or by Semex USA. Major AI organizations have controller codes between 1 and 222, excluding 100; AI organizations with a code of 100 or $\geq 2000$ market but do not process semen and are considered to be "marketing-only" organizations. Holstein bulls were categorized as 1) PT through a major AI organization, 2) PT through a marketingonly AI organization, 3) proven through a major AI organization, 4) proven through a marketing-only AI organization, 5) marketed through AI based on an NS evaluation (breeder proven), or 6) used through NS. Bulls proven through AI or breeder proven and then marketed through AI had daughters born $\geq 43$ mo after bull entry into AI. Sampling controller codes were not assigned prior to 1990 (Sattler, 1990); therefore, the controller code assigned by the National Association of Animal Breeders was used for those bulls. Characteristics were summarized by year entered AI or by year of first parity, and results were reported for representative years or the mean of several years.

Many previously unreported characteristics of AI PT programs were documented. Mean age of bulls when semen was released, mean age of bulls when daughters were born, and mean age of bulls when daughters calved were calculated and summarized. Mean calving age of daughters of PT bulls was calculated from differences between age when daughters were born and calved. Concentration of PT daughters in US herds was detailed, including frequency distribution of the percentage of herds with various percentages of PT daughters and the percentage of PT daughters represented in those same herds. Mean ages of PT bulls when daughters were born and calved were calculated by year of first calving and herd percentage of PT daughters. Percentage of bulls returning to AI service after PT was determined. All statistics were calculated separately by breed and year since 1960 . For a bull to be considered to have returned to AI service, the number of daughters calving after AI sampling had to exceed 50 or $100 \%$ of the number included in the PT sample. Two definitions for return to AI service were used to determine the impact of the definition criterion on the estimate of selection intensity.

Numbers of daughters that were sired by bulls of each AI-status category (PT, AI proven, and NS) provided an indication of changes in AI contribution across time. Records of PT daughters for milk, fat, and protein yields provided an opportunity to compare performance of PT daughters with that of daughters of AI-proven and NS bulls. Sire PTA for milk, fat, and protein from the national dairy database were used to compare genetic merit of PT, AI-proven, and NS bulls available to producers at the same time. Mean PTA for milk, fat, and protein of Holstein PT bulls were examined by calendar month of semen release using models that included perpetual day (linear and quadratic) to remove the effect attributed to overall genetic trend.

\section{RESULTS AND DISCUSSION}

Table 1 shows means and standard deviation of age of PT bulls when semen was released by major AI 
Table 1. Means and standard deviations of ages of progeny-test bulls when semen was released by major AI organizations ${ }^{1}$ by year of bull entry into AI sampling and breed.

\begin{tabular}{|c|c|c|c|c|c|c|c|c|c|c|c|c|}
\hline \multirow[b]{2}{*}{ Years } & \multicolumn{2}{|c|}{ Ayrshire } & \multicolumn{2}{|c|}{ Brown Swiss } & \multicolumn{2}{|c|}{ Guernsey } & \multicolumn{2}{|c|}{ Holstein } & \multicolumn{2}{|c|}{ Jersey } & \multicolumn{2}{|c|}{$\begin{array}{l}\text { Milking } \\
\text { Shorthorn }\end{array}$} \\
\hline & Mean & $\mathrm{SD}$ & Mean & SD & Mean & SD & Mean & $\mathrm{SD}$ & Mean & $\mathrm{SD}$ & Mean & $\mathrm{SD}$ \\
\hline & & & & & & $-(\mathrm{m}$ & & & & & & \\
\hline 1960-1964 & 16.1 & 3.0 & 17.1 & 5.0 & 15.5 & 3.3 & 15.2 & 4.3 & 15.3 & 4.2 & 20.3 & 5.1 \\
\hline 1965-1969 & 14.6 & 2.3 & 16.1 & 3.5 & 15.5 & 4.7 & 15.2 & 3.7 & 16.3 & 5.2 & 11.4 & 0.6 \\
\hline 1970-1974 & 18.4 & 4.2 & 16.6 & 4.4 & 15.8 & 3.9 & 14.7 & 2.9 & 16.1 & 3.3 & 16.1 & 3.8 \\
\hline 1975-1979 & 19.4 & 3.6 & 15.9 & 3.8 & 16.6 & 3.6 & 16.0 & 2.8 & 17.2 & 3.2 & 17.4 & 5.1 \\
\hline 1980-1984 & 18.6 & 3.7 & 16.3 & 3.1 & 16.4 & 2.9 & 16.3 & 3.0 & 16.9 & 3.3 & 17.3 & 2.9 \\
\hline 1985-1989 & 19.0 & 4.9 & 15.1 & 2.5 & 15.8 & 3.2 & 15.6 & 2.8 & 15.8 & 2.9 & 15.2 & 2.5 \\
\hline 1990-1994 & 18.5 & 4.1 & 16.4 & 3.3 & 16.3 & 3.4 & 15.6 & 2.4 & 16.3 & 3.4 & 15.9 & 3.5 \\
\hline 1995-1998 & 17.9 & 3.2 & 16.3 & 2.8 & 16.1 & 2.4 & 16.0 & 2.4 & 15.8 & 2.8 & 19.2 & 5.1 \\
\hline
\end{tabular}

\footnotetext{
${ }^{1}$ Major AI organizations had a sampling controller or controller code of 1 through 99 and 101 through
} 222 as assigned by the National Association of Animal Breeders (Columbia, MO).

organizations. No obvious trends in means were apparent for any breed. Nonetheless, small increases were significant $(P<0.001$ for Holsteins; $P<0.05$ for Ayrshires). The linear regression coefficient for Holsteins was $0.018 \mathrm{mo} / \mathrm{yr}$, which is equivalent to $60 \mathrm{yr}$ to produce a 1-mo increase in semen release age, but was larger $(0.051 \mathrm{mo} / \mathrm{yr})$ for Ayrshires. Mean age when semen was released from 1995 through 1998 was 16 mo for Brown Swiss, Guernseys, Holsteins, and Jerseys; 18 mo for Ayrshires; and 19 mo for Milking Shorthorns. Holstein mean at 16 mo was the same as reported during the late 1970s and early 1980s (Norman and Powell, 1986). Fluctuations in SD were substantial across time. However, overall decrease in SD indicates more uniformity in age at semen release (because fewer bulls had delayed semen release dates). Mean age of PT bulls when semen was released by marketing-only AI organizations (not shown) was lower (0.6 to $2.1 \mathrm{mo}$ ) than for major AI organizations for all year groups except 1970 to 1974; SD of PT bull age at semen release for marketing-only AI organizations (not shown) was generally slightly higher (by up to $0.8 \mathrm{mo}$ ) than for major AI organizations. An examination to determine whether the major AI organizations differed in mean age of PT bulls when semen was released revealed significant differences $(P<0.001)$.

Table 2 shows a distribution of age of bulls when semen was released by major AI organizations during the 1990s. Of Holstein bulls sampled during the 1990s, $10 \%$ had semen released before they were 12.8 mo of age and $90 \%$ by 18.8 mo. Age distribution at semen release was similar for other breeds, but Ayrshires were older regardless of percentage of PT bulls with semen released. An imposed data edit did not allow a bull to be coded as PT if semen was not released by the time the bull reached 29.5 mo of age.

Table 3 shows means and SD for age of PT bulls when daughters were born by breed and year of AI sampling by major AI organizations. For bulls that were sampled from 1990 through 1994, mean bull age at daughter birth was 29.2 mo for Holsteins, 32.5 mo for Jerseys, and 34.5 to 39.0 mo for other breeds. Mean

Table 2. Distribution of bull ages at semen release by percentage of bulls with semen released for AI sampling by major AI organizations ${ }^{1}$ from 1990 through 1998 and breed.

\begin{tabular}{llllll}
\hline $\begin{array}{l}\text { Percentage of progeny-test } \\
\text { bulls with semen released }\end{array}$ & Ayrshire & $\begin{array}{l}\text { Brown } \\
\text { Swiss }\end{array}$ & Guernsey & Holstein & Jersey \\
\hline & 14.1 & 12.7 & 12.8 & & \\
\cline { 2 - 5 } 10 & 14.8 & 13.4 & 13.7 & 12.8 & 12.6 \\
20 & 15.5 & 14.3 & 14.5 & 14.3 & 13.4 \\
30 & 16.9 & 15.4 & 15.0 & 14.9 & 14.2 \\
40 & 18.2 & 16.2 & 15.6 & 15.5 & 15.5 \\
50 & 19.3 & 16.9 & 16.4 & 16.1 & 16.1 \\
60 & 20.5 & 17.5 & 17.2 & 16.7 & 17.1 \\
70 & 21.4 & 18.5 & 18.4 & 17.5 & 18.3 \\
80 & 22.6 & 20.5 & 20.4 & 18.8 & 20.5 \\
90 & 29.1 & 28.2 & 26.7 & 29.4 & 29.5 \\
100 & & & & & \\
\end{tabular}

\footnotetext{
${ }^{1}$ Major AI organizations had a sampling controller or controller code of 1 through 99 and 101 through 222 as assigned by the National Association of Animal Breeders (Columbia, MO).
} 
Table 3. Means and standard deviations of ages of progeny-test bulls when daughters ${ }^{1}$ were born by year of bull entry into AI sampling by major $\mathrm{AI}$ organizations ${ }^{2}$ and breed.

\begin{tabular}{|c|c|c|c|c|c|c|c|c|c|c|c|c|}
\hline \multirow[b]{2}{*}{ Years } & \multicolumn{2}{|c|}{ Ayrshire } & \multicolumn{2}{|c|}{$\begin{array}{l}\text { Brown } \\
\text { Swiss }\end{array}$} & \multicolumn{2}{|c|}{ Guernsey } & \multicolumn{2}{|c|}{ Holstein } & \multicolumn{2}{|c|}{ Jersey } & \multicolumn{2}{|c|}{$\begin{array}{l}\text { Milking } \\
\text { Shorthorn }\end{array}$} \\
\hline & Mean & SD & Mean & SD & Mean & SD & Mean & SD & Mean & SD & Mean & SD \\
\hline & & & & & & -1 & & & & & & \\
\hline 1960-1964 & 35.8 & 6.2 & 41.0 & 5.4 & 36.8 & 5.5 & 33.9 & 6.8 & 36.9 & 5.0 & 44.6 & 8.5 \\
\hline 1965-1969 & 37.5 & 4.7 & 41.0 & 5.7 & 38.0 & 5.3 & 31.9 & 5.9 & 38.3 & 6.2 & 39.3 & 3.1 \\
\hline $1970-1974$ & 39.2 & 6.4 & 41.6 & 5.0 & 37.9 & 4.6 & 32.6 & 5.7 & 37.7 & 4.6 & 44.0 & 5.4 \\
\hline $1975-1979$ & 39.3 & 4.8 & 39.5 & 3.8 & 37.3 & 4.1 & 32.4 & 5.1 & 38.0 & 4.9 & 43.3 & 5.7 \\
\hline 1980-1984 & 38.7 & 4.2 & 39.9 & 3.8 & 35.4 & 3.8 & 31.8 & 5.2 & 35.4 & 4.4 & 42.3 & 5.0 \\
\hline 1985-1989 & 39.1 & 4.3 & 37.7 & 4.0 & 34.6 & 4.4 & 30.2 & 4.5 & 33.2 & 3.5 & 39.8 & 2.8 \\
\hline 1990-1994 & 36.4 & 4.0 & 35.8 & 4.3 & 34.5 & 3.9 & 29.2 & 3.2 & 32.5 & 3.9 & 39.0 & 6.5 \\
\hline
\end{tabular}

${ }^{1}$ First 125 daughters that were born between 8 and 42 mo after entry of a bull into AI and that had records that contributed to the genetic evaluation of that bull.

${ }^{2}$ Major AI organizations had a sampling controller or controller code of 1 through 99 and 101 through 222 as assigned by the National Association of Animal Breeders (Columbia, MO).

age of PT bulls when daughters were born has declined for all breeds as confirmed by linear regression coefficients (not shown, $P<0.001$ ). If both linear and quadratic coefficients were included, both showed significance (Milking Shorthorn, $P<0.01$; other breeds, $P<$ 0.001 ). Mean PT bull age at daughter birth is lower by 3.4 mo for Holsteins and 2.8 to 5.8 mo for other breeds for bulls sampled from 1990 through 1994 compared with those sampled from 1970 through 1974; SD also decreased for all breeds except Milking Shorthorn.
The SD decreased from 5.7 to 3.2 mo for Holsteins. Reduction in SD is probably one of the main reasons that mean age of bulls at daughters birth also declined. The results indicate that distributed semen is used more rapidly than during earlier years. Mean age of PT bulls at daughter birth was higher (usually 3.2 to $4.8 \mathrm{mo}$ ) for marketing-only AI organizations (not shown) than for major AI organizations for all year groups. Although bulls from marketing-only AI organizations were younger when semen was released, this

Table 4. Mean bull ages by year of entry into AI sampling by major AI organizations, ${ }^{1}$ percentage of progenytest daughters ${ }^{2}$ born, and breed.

\begin{tabular}{|c|c|c|c|c|c|c|}
\hline Years & $\begin{array}{l}\text { Percentage of } \\
\text { progeny-test } \\
\text { daughters born }\end{array}$ & Ayrshire & $\begin{array}{l}\text { Brown } \\
\text { Swiss }\end{array}$ & Guernsey & Holstein & Jersey \\
\hline & & & - & $-(\mathrm{mo})$ & & \\
\hline \multirow[t]{10}{*}{ 1970-1979 } & 10 & 30.9 & 30.0 & 29.5 & 27.2 & 29.7 \\
\hline & 20 & 32.8 & 32.4 & 31.3 & 28.1 & 31.3 \\
\hline & 30 & 34.8 & 34.6 & 32.7 & 29.1 & 32.9 \\
\hline & 40 & 36.5 & 36.6 & 34.5 & 30.0 & 34.6 \\
\hline & 50 & 38.2 & 39.1 & 36.3 & 31.1 & 36.6 \\
\hline & 60 & 40.0 & 42.0 & 38.5 & 32.3 & 38.9 \\
\hline & 70 & 42.3 & 44.6 & 41.0 & 33.7 & 41.2 \\
\hline & 80 & 44.7 & 47.6 & 43.9 & 35.8 & 43.9 \\
\hline & 90 & 48.2 & 51.3 & 48.1 & 39.4 & 47.7 \\
\hline & 100 & 55.0 & 55.1 & 54.3 & 48.1 & 53.6 \\
\hline \multirow[t]{10}{*}{ 1990-1994 } & 10 & 30.3 & 29.0 & 28.6 & 26.1 & 27.5 \\
\hline & 20 & 31.3 & 30.4 & 29.6 & 26.5 & 28.4 \\
\hline & 30 & 32.3 & 31.5 & 30.6 & 27.0 & 29.1 \\
\hline & 40 & 33.8 & 32.6 & 31.7 & 27.5 & 30.0 \\
\hline & 50 & 34.9 & 34.0 & 32.9 & 28.0 & 31.0 \\
\hline & 60 & 36.6 & 35.7 & 34.4 & 28.7 & 32.2 \\
\hline & 70 & 38.4 & 38.0 & 36.5 & 29.7 & 33.7 \\
\hline & 80 & 40.9 & 40.5 & 39.4 & 31.1 & 35.8 \\
\hline & 90 & 44.7 & 45.2 & 43.9 & 33.8 & 39.5 \\
\hline & 100 & 52.8 & 50.5 & 50.2 & 43.6 & 48.6 \\
\hline
\end{tabular}

${ }^{1}$ Major AI organizations had a sampling controller or controller code of 1 through 99 and 101 through 222 as assigned by the National Association of Animal Breeders (Columbia, MO).

${ }^{2}$ First 125 daughters that were born between 8 and 42 mo after entry of a bull into AI and that had records that contributed to the genetic evaluation of that bull. 
Table 5. Means and standard deviations of ages of progeny-test bulls when daughters ${ }^{1}$ calved by year of bull entry into AI sampling by major AI organizations ${ }^{2}$ and breed.

\begin{tabular}{|c|c|c|c|c|c|c|c|c|c|c|c|c|}
\hline \multirow[b]{2}{*}{ Years } & \multicolumn{2}{|c|}{ Ayrshire } & \multicolumn{2}{|c|}{$\begin{array}{l}\text { Brown } \\
\text { Swiss }\end{array}$} & \multicolumn{2}{|c|}{ Guernsey } & \multicolumn{2}{|c|}{ Holstein } & \multicolumn{2}{|c|}{ Jersey } & \multicolumn{2}{|c|}{$\begin{array}{l}\text { Milking } \\
\text { Shorthorn }\end{array}$} \\
\hline & Mean & SD & Mean & SD & Mean & $\mathrm{SD}$ & Mean & SD & Mean & SD & Mean & SD \\
\hline & & & & & & & & & & & & \\
\hline 1960-1964 & 65.5 & 5.6 & 69.7 & 5.5 & 64.8 & 5.7 & 61.6 & 7.1 & 63.5 & 5.0 & 73.4 & 6.5 \\
\hline $1965-1969$ & 66.5 & 4.8 & 69.6 & 6.0 & 66.0 & 5.6 & 59.8 & 6.0 & 65.1 & 6.3 & 67.2 & 2.7 \\
\hline 1970-1974 & 68.3 & 6.2 & 70.2 & 5.5 & 66.0 & 4.7 & 60.8 & 5.9 & 64.5 & 4.9 & 72.9 & 4.9 \\
\hline $1975-1979$ & 68.8 & 4.7 & 67.9 & 3.8 & 65.2 & 4.1 & 60.4 & 5.3 & 64.4 & 5.1 & 72.0 & 6.2 \\
\hline $1980-1984$ & 67.9 & 4.3 & 68.4 & 4.0 & 63.1 & 4.0 & 59.6 & 5.4 & 61.7 & 4.4 & 70.3 & 5.7 \\
\hline 1985-1989 & 67.8 & 4.2 & 65.6 & 4.0 & 62.1 & 4.5 & 57.2 & 4.6 & 59.0 & 3.7 & 67.4 & 2.9 \\
\hline 1990-1994 & 64.7 & 4.1 & 63.7 & 4.4 & 61.8 & 4.0 & 55.6 & 3.3 & 58.0 & 4.1 & 65.4 & 6.8 \\
\hline
\end{tabular}

${ }^{1}$ First 125 daughters that were born between 8 and 42 mo after entry of a bull into AI and that had records that contributed to the genetic evaluation of that bull.

${ }^{2}$ Major AI organizations had a sampling controller or controller code of 1 through 99 and 101 through 222 as assigned by the National Association of Animal Breeders (Columbia, MO).

advantage dissipated as daughters were born, perhaps because the major AI organizations delivered semen more rapidly to the farms or were more persuasive in getting cows bred sooner after semen arrived. The SD of mean age of PT bulls from marketing-only AI organizations at daughter birth (not shown) was larger (usually by 0.4 to $2.7 \mathrm{mo}$ ) than for major AI organizations. The major AI organizations differed $(P<0.001)$ in mean age of bulls when daughters were born.

Table 4 shows mean ages of bulls from major AI organizations by percentage of PT daughters born across time. The few bulls with semen distributed without restriction on number of units shipped to the field should not bias means or SD of ages upward because only the first 125 daughters of individual bulls were included in the means. For Holsteins during the $1990 \mathrm{~s}$, mean bull age was 26.1 mo before the first $10 \%$ of PT daughters were born and 28.0 mo before half of PT daughters were born. The interval required for birth of each additional $10 \%$ of PT daughters increased after the first $50 \%$. The pace of producing Holstein PT daughters has improved substantially since the 1970s. Mean Holstein bull age when $80 \%$ of PT daughters were born (not all shown) was 35.9, 35.8, 33.2, and 31.1 mo during the four decades from the 1960s through the 1990s, respectively. For Brown Swiss and Jerseys, mean bull age when $80 \%$ of daughters were born decreased even more during those four decades ( 8.4 and 8.3 mo, respectively); however, mean bull age when $80 \%$ of PT daughters were born was still higher during the 1990s for those two breeds than for Holsteins by 9.4 and 4.7 mo. Elapsed time between birth of 50 and $90 \%$ of PT daughters during the 1990 s was 5.8 mo for Holsteins but ranged from 8.5 to 11.2 mo for other breeds. Why other breeds require more time than Holsteins for birth of PT daughters may be related to the number or size of PT herds or to the intensity of effort of the AI organizations because of differing economic opportunities. Either distribution of semen to producers takes longer for breeds other than Holstein, those producers wait longer to use the semen, or breed differences in fertility exist.

Table 5 shows means and SD for age of bulls when PT daughters calved by breed and year of AI sampling by major AI organizations. For bulls that were sampled from 1990 through 1994, mean age of PT bulls at daughter calving was 55.6 and 58.0 mo for Holsteins and Jerseys, respectively, and 61.8 to 65.4 mo for other breeds. Because mean age of PT bulls when daughters were born decreased over time, not surprisingly mean age of PT bulls when daughters calved also decreased. The negative regression coefficients for age when daughters calved on year were even larger than for mean age of bulls when daughters were born. Coefficients for both linear and linear-quadratic regression were significant $(P<0.001)$ for all breeds. The larger negative regression on year for bull age at daughter calving than for bull age at daughter birth resulted from a reduction in calving age for first-parity cows because the age of bulls when daughters calved is a function of the age of the bulls when the daughters were born and the mean daughter age at first calving. Mean age of PT bulls when daughters calved was lower from 1990 through 1994 than from 1970 through 1974 by 3.6 to 7.5 mo depending on breed; mean age of Holstein PT bulls at daughter calving declined by 5.2 mo. The SD of age of PT bulls at daughter calving followed a decrease similar to that for age of PT bulls at daughter birth. For Holsteins, SD of PT bull age when daughters calved decreased from 5.9 mo during the 1970 s to 3.3 mo during the 1990 s. The decrease 
Table 6. Mean bull ages by year of entry into AI sampling by major AI organizations, ${ }^{1}$ percentage of progenytest daughters ${ }^{2}$ that had calved, and breed.

\begin{tabular}{|c|c|c|c|c|c|c|}
\hline Years & $\begin{array}{l}\text { Percentage of } \\
\text { progeny-test } \\
\text { daughters that } \\
\text { had calved }\end{array}$ & Ayrshire & $\begin{array}{l}\text { Brown } \\
\text { Swiss }\end{array}$ & Guernsey & Holstein & Jersey \\
\hline & & & & $-(\mathrm{mo})$ & & \\
\hline \multirow[t]{10}{*}{ 1970-1979 } & 10 & 59.5 & 57.6 & 56.3 & 53.4 & 55.2 \\
\hline & 20 & 61.9 & 60.5 & 58.7 & 55.1 & 57.4 \\
\hline & 30 & 63.8 & 63.1 & 60.7 & 56.6 & 59.4 \\
\hline & 40 & 65.8 & 65.4 & 62.6 & 58.0 & 61.3 \\
\hline & 50 & 68.0 & 67.8 & 64.7 & 59.5 & 63.4 \\
\hline & 60 & 69.8 & 70.7 & 66.9 & 61.1 & 65.6 \\
\hline & 70 & 71.8 & 73.5 & 69.6 & 63.0 & 68.1 \\
\hline & 80 & 74.5 & 76.5 & 72.4 & 65.3 & 70.9 \\
\hline & 90 & 78.1 & 80.0 & 76.6 & 68.8 & 74.9 \\
\hline & 100 & 85.0 & 85.2 & 83.4 & 77.3 & 81.6 \\
\hline \multirow[t]{10}{*}{ 1990-1994 } & 10 & 56.9 & 55.5 & 54.3 & 50.4 & 51.5 \\
\hline & 20 & 58.9 & 57.4 & 56.0 & 51.6 & 52.9 \\
\hline & 30 & 60.6 & 59.1 & 57.5 & 52.6 & 54.2 \\
\hline & 40 & 62.1 & 60.7 & 59.0 & 53.5 & 55.4 \\
\hline & 50 & 63.9 & 62.4 & 60.4 & 54.6 & 56.7 \\
\hline & 60 & 65.8 & 64.2 & 62.3 & 55.8 & 58.2 \\
\hline & 70 & 67.7 & 66.5 & 64.8 & 57.2 & 60.1 \\
\hline & 80 & 70.3 & 69.2 & 67.5 & 59.2 & 62.5 \\
\hline & 90 & 74.1 & 73.6 & 72.0 & 62.2 & 66.2 \\
\hline & 100 & 82.0 & 79.4 & 78.5 & 71.5 & 75.3 \\
\hline
\end{tabular}

${ }^{1}$ Major AI organizations had a sampling controller or controller code of 1 through 99 and 101 through 222 as assigned by the National Association of Animal Breeders (Columbia, MO).

${ }^{2}$ First 125 daughters that were born between 8 and 42 mo after entry of a bull into AI and that had records that contributed to the genetic evaluation of that bull.

indicates a higher percentage of daughters have milk records available in a timely manner and, therefore, information from more daughters probably is included in genetic evaluations before the fate of the PT bull is determined. That decrease also indicated that PT daughters were distributed across fewer seasons of the year, which increases the importance of appropriate modeling of environmental effects when computing genetic evaluations. Means of ages of PT bulls from mar- keting-only AI organizations at daughter calving (not shown) were higher (usually by 3.6 to $5.7 \mathrm{mo}$ ) than for PT bulls from major AI organizations for all age groups, which parallels the older age of bulls at daughter birth for marketing-only AI organizations compared with major AI organizations. The SD for PT bull age when daughters calved for marketing-only AI organizations (not shown) varied more (usually 0.5 to $2.8 \mathrm{mo}$ ) than corresponding SD for major AI organiza-

Table 7. Means and standard deviations of progeny-test bull means of calving age of daughters ${ }^{1}$ by year of bull entry into AI sampling by major AI organizations ${ }^{2}$ and breed.

\begin{tabular}{|c|c|c|c|c|c|c|c|c|c|c|c|c|}
\hline \multirow[b]{2}{*}{ Years } & \multicolumn{2}{|c|}{ Ayrshire } & \multicolumn{2}{|c|}{$\begin{array}{l}\text { Brown } \\
\text { Swiss }\end{array}$} & \multicolumn{2}{|c|}{ Guernsey } & \multicolumn{2}{|c|}{ Holstein } & \multicolumn{2}{|c|}{ Jersey } & \multicolumn{2}{|c|}{$\begin{array}{l}\text { Milking } \\
\text { Shorthorn }\end{array}$} \\
\hline & Mean & SD & Mean & SD & Mean & SD & Mean & SD & Mean & SD & Mean & SD \\
\hline & & & & & & & & & & & & \\
\hline 1960-1964 & 29.7 & 1.6 & 28.7 & 0.9 & 28.0 & 1.1 & 27.6 & 1.2 & 26.5 & 0.8 & 28.7 & 2.5 \\
\hline 1965-1969 & 29.0 & 0.4 & 28.5 & 1.2 & 28.0 & 1.1 & 27.9 & 1.0 & 26.7 & 0.8 & 27.9 & 0.3 \\
\hline 1970-1974 & 29.1 & 0.6 & 28.6 & 0.8 & 28.1 & 1.1 & 28.3 & 1.0 & 26.8 & 0.9 & 28.9 & 1.9 \\
\hline 1975-1979 & 29.5 & 0.4 & 28.4 & 0.9 & 27.9 & 0.9 & 28.1 & 1.0 & 26.4 & 0.8 & 28.8 & 1.1 \\
\hline 1980-1984 & 29.2 & 0.6 & 28.5 & 1.1 & 27.7 & 0.8 & 27.8 & 1.0 & 26.3 & 0.8 & 28.0 & 0.7 \\
\hline 1985-1989 & 28.7 & 1.0 & 27.9 & 0.7 & 27.5 & 0.7 & 27.0 & 0.9 & 25.9 & 0.7 & 27.6 & 0.7 \\
\hline 1990-1994 & 28.4 & 0.9 & 27.9 & 0.7 & 27.3 & 0.8 & 26.4 & 0.7 & 25.5 & 0.8 & 26.4 & 0.7 \\
\hline
\end{tabular}

${ }^{1}$ First 125 daughters that were born between 8 and 42 mo after entry of a bull into AI and that had records that contributed to the genetic evaluation of that bull.

${ }^{2}$ Major AI organizations had a sampling controller or controller code of 1 through 99 and 101 through 222 as assigned by the National Association of Animal Breeders (Columbia, MO). 
Table 8. Distribution of Holstein herds and progeny-test daughters by year of first calving and herd use of progeny-test bulls from major AI organizations. ${ }^{1}$

\begin{tabular}{|c|c|c|c|c|c|c|c|}
\hline \multirow[b]{2}{*}{ Distribution } & \multirow[b]{2}{*}{ Year } & \multicolumn{6}{|c|}{ Herd use of progeny-test bulls (\%) } \\
\hline & & 0 & $1-9$ & $10-19$ & $20-49$ & 50-99 & 100 \\
\hline \multirow{6}{*}{ Herd } & 1965 & 85 & 4 & 6 & 4 & 1 & $<0.1$ \\
\hline & 1975 & 68 & 11 & 11 & 9 & 1 & $<0.1$ \\
\hline & 1985 & 56 & 17 & 15 & 11 & 1 & 0.1 \\
\hline & 1990 & 51 & 19 & 16 & 12 & 2 & 0.1 \\
\hline & 1995 & 41 & 20 & 19 & 16 & 3 & 0.3 \\
\hline & 1998 & 39 & 19 & 19 & 18 & 5 & 0.4 \\
\hline \multirow[t]{6}{*}{ Progeny-test daughters } & 1965 & 0 & 18 & 32 & 38 & 11 & 0.1 \\
\hline & 1975 & 0 & 19 & 31 & 44 & 6 & 0.1 \\
\hline & 1985 & 0 & 20 & 33 & 40 & 7 & 0.3 \\
\hline & 1990 & 0 & 18 & 32 & 38 & 12 & 0.6 \\
\hline & 1995 & 0 & 14 & 27 & 42 & 15 & 1.0 \\
\hline & 1998 & 0 & 11 & 24 & 41 & 23 & 1.1 \\
\hline
\end{tabular}

${ }^{1}$ Major AI organizations had a sampling controller or controller code of 1 through 99 and 101 through 222 as assigned by the National Association of Animal Breeders (Columbia, MO).

tions. Again, the major AI organizations differed $(P<$ 0.001) in mean age of bulls at daughter calvings.

During the $1990 \mathrm{~s}$, mean Holstein PT bull age was 50.4 mo before the first $10 \%$ of daughters calved and 54.6 mo before half of daughters calved (Table 6). The time to reach each additional $10 \%$ of PT daughters calving generally increased after the first half of PT daughters had calved. Mean Holstein PT bull ages when $80 \%$ of daughters calved (not all shown) were $65.1,65.3,62.1$, and 59.2 mo during the four decades from the 1960s through $1990 \mathrm{~s}$, respectively. The decline in interval from first daughter calvings to when information from most daughters is available for evaluation of the bull is of interest. The interval between 10 and $80 \%$ of daughter calvings was 11.9 mo during the $1970 \mathrm{~s}$ and $8.8 \mathrm{mo}$ during the $1990 \mathrm{~s}$. The shortened interval for determining the future AI status of a bull benefits bull owners through reduced feeding and housing costs if the bull is not returned to AI service and earlier income from semen sales if the bull is returned to service. Mean PT bull ages when $80 \%$ of daughters had calved were 3.3 to 11.1 mo lower for Holsteins than for other breeds during the 1990s. Most AI organizations decide which PT bulls to graduate to active AI service based on first and second evaluations; unfortunately, precise information on the age when the return-to-service decision is made is not recorded. Nevertheless, the final $10 \%$ of PT daughters often are born and calve too late for those decisions.

Table 7 shows means and SD for PT bull mean of calving age of daughters for major AI organizations. Bull mean for calving age of PT daughters declined by about 1 mo over $30 \mathrm{yr}$ for most breeds and ranged from 26 to 28 mo during that period. The SD of bull means

Table 9. Mean ages of progeny-test bulls at daughter birth and calving by year of first calving and herd use of progeny-test bulls.

\begin{tabular}{|c|c|c|c|c|c|c|}
\hline \multirow[b]{2}{*}{ Daughter trait } & \multirow[b]{2}{*}{ Year } & \multicolumn{5}{|c|}{ Herd use of progeny-test bulls (\%) } \\
\hline & & $1-9$ & $10-19$ & $20-49$ & $50-99$ & 100 \\
\hline & & & & $(\mathrm{mo})$ & & \\
\hline \multirow[t]{6}{*}{ Birth } & 1965 & 33.3 & 33.4 & 31.7 & 30.2 & \\
\hline & 1975 & 32.4 & 31.5 & 31.0 & 32.7 & \\
\hline & 1985 & 32.1 & 31.4 & 31.7 & 31.7 & 25.9 \\
\hline & 1990 & 31.5 & 30.0 & 29.4 & 29.3 & 27.2 \\
\hline & 1995 & 31.3 & 29.7 & 29.0 & 28.3 & 26.7 \\
\hline & 1998 & 31.7 & 30.4 & 29.1 & 28.4 & 27.3 \\
\hline \multirow[t]{6}{*}{ Calving } & 1965 & 60.9 & 61.0 & 59.0 & 57.6 & $\ldots$ \\
\hline & 1975 & 60.1 & 59.1 & 58.7 & 60.8 & \\
\hline & 1985 & 60.0 & 59.1 & 59.6 & 59.9 & 54.6 \\
\hline & 1990 & 58.4 & 56.9 & 56.4 & 56.4 & 55.3 \\
\hline & 1995 & 57.6 & 55.9 & 55.2 & 54.6 & 54.2 \\
\hline & 1998 & 57.8 & 56.4 & 55.2 & 54.3 & 53.5 \\
\hline
\end{tabular}


Table 10. Percentages of bulls that returned to AI service after progeny testing and that had 50 or $100 \%$ more daughters by year of bull entry into AI sampling by major AI organizations ${ }^{1}$ and breed.

\begin{tabular}{lllllll}
\hline $\begin{array}{l}\text { Daughter increase } \\
\text { after progeny test }\end{array}$ & $\begin{array}{l}\text { Years of bull entry } \\
\text { into AI sampling }\end{array}$ & Ayrshire & $\begin{array}{l}\text { Brown } \\
\text { Swiss }\end{array}$ & Guernsey & Holstein & Jersey \\
\hline & & & & & & \\
\cline { 2 - 6 } $50 \%$ & $1963-1967$ & 71 & 48 & 36 & 44 & 46 \\
& $1968-1972$ & 57 & 88 & 44 & 45 & 50 \\
& $1973-1977$ & 67 & 62 & 32 & 39 & 56 \\
& $1978-1982$ & 46 & 51 & 36 & 20 & 38 \\
$100 \%$ & $1983-1987$ & 37 & 46 & 28 & 19 & 26 \\
& $1988-1992$ & 23 & 19 & 22 & 14 & 19 \\
& $1963-1967$ & 57 & 24 & 21 & 31 & 32 \\
& $1968-1972$ & 50 & 65 & 23 & 32 & 35 \\
& $1973-1977$ & 50 & 38 & 25 & 28 & 38 \\
& $1978-1982$ & 24 & 30 & 31 & 15 & 26 \\
& $1983-1987$ & 22 & 35 & 21 & 14 & 23 \\
\hline
\end{tabular}

${ }^{1}$ Major AI organizations had a sampling controller or controller code of 1 through 99 and 101 through 222 as assigned by the National Association of Animal Breeders (Columbia, MO).

were variable for Ayrshires, Brown Swiss, and Milking Shorthorns, and they declined for Guernseys and Holsteins. Smaller SD indicate more uniform management in the sampling population, which is a desirable characteristic.

Norman et al. (2001) reported that percentage of first-parity Holstein cows that were PT daughters increased from $4 \%$ during 1965 to $14 \%$ during 1998. Table 8 shows the large increase in percentage of Holstein herds with first-parity daughters of PT bulls and various levels of participation in PT programs. During $1965,85 \%$ of tested herds had no first-parity daughters of PT bulls. This percentage declined to $39 \%$ by 1998 , which indicated that the majority of dairy producers on DHI test currently contributed to PT programs. Some of this contribution may be because of sale of PT daughters into herds that do not use sample sires. Most of the herds that used PT bulls in 1998 had $<20 \%$ PT daughters with equal percentages of herds with 1 to $9 \%$ and 10 to $19 \%$ use of PT bulls. Table 8 also shows percentages of total PT daughters that are in the herds with those same levels of PT use. In contrast to herd participation, two-thirds of PT daughters are in herds with $>20 \%$ PT daughters.

Mean ages of PT bulls when daughters were born and calved across time (Table 9) shows the relationship

Table 11. Numbers and percentages of Holstein cows by year of first calving and AI status ${ }^{1}$ of sire.

\begin{tabular}{|c|c|c|c|c|c|c|c|c|c|c|c|c|}
\hline \multirow[b]{3}{*}{ Year } & \multicolumn{4}{|c|}{ Progeny test } & \multicolumn{4}{|c|}{ AI proven } & \multirow{2}{*}{\multicolumn{2}{|c|}{$\begin{array}{c}\text { Natural- } \\
\text { service } \\
\text { proven, } \\
\text { AI marketed }\end{array}$}} & \multirow{2}{*}{\multicolumn{2}{|c|}{$\begin{array}{c}\text { Natural } \\
\text { service } \\
\text { use only }\end{array}$}} \\
\hline & \multicolumn{2}{|c|}{ Major AI } & \multicolumn{2}{|c|}{$\begin{array}{l}\text { Marketing- } \\
\text { only AI }\end{array}$} & \multicolumn{2}{|c|}{ Major AI } & \multicolumn{2}{|c|}{$\begin{array}{l}\text { Marketing- } \\
\text { only AI }\end{array}$} & & & & \\
\hline & (no.) & $(\%)$ & (no.) & $(\%)$ & (no.) & $(\%)$ & (no.) & $(\%)$ & (no.) & $(\%)$ & (no.) & $(\%)$ \\
\hline 1984 & 40,794 & 8 & 1722 & $<1$ & 322,469 & 61 & 1770 & $<1$ & 97,685 & 19 & 61,134 & 12 \\
\hline 1985 & 46,378 & 8 & 4198 & 1 & 360,576 & 61 & 4436 & 1 & 117,416 & 20 & 61,802 & 10 \\
\hline 1986 & 46,381 & 8 & 5605 & 1 & 341,752 & 59 & 6734 & 1 & 122,790 & 21 & 55,659 & 10 \\
\hline 1987 & 49,590 & 8 & 8254 & 1 & 351,914 & 59 & 10,285 & 2 & 121,862 & 20 & 56,625 & 9 \\
\hline 1988 & 51,075 & 8 & 9848 & 2 & 387,916 & 64 & 13,135 & 2 & 92,501 & 15 & 55,736 & 9 \\
\hline 1989 & 57,681 & 9 & 11,231 & 2 & 426,667 & 68 & 18,658 & 3 & 53,160 & 9 & 57,822 & 9 \\
\hline 1990 & 58,606 & 9 & 13,896 & 2 & 432,126 & 69 & 30,518 & 5 & 39,456 & 6 & 56,169 & 9 \\
\hline 1991 & 64,981 & 10 & 16,787 & 3 & 434,658 & 66 & 46,764 & 7 & 39,906 & 6 & 55,582 & 8 \\
\hline 1992 & 68,733 & 10 & 18,137 & 3 & 417,398 & 62 & 66,556 & 10 & 44,631 & 7 & 53,383 & 8 \\
\hline 1993 & 67,247 & 10 & 18,404 & 3 & 414,578 & 62 & 77,922 & 12 & 39,809 & 6 & 48,973 & 7 \\
\hline 1994 & 74,421 & 11 & 20,837 & 3 & 406,982 & 62 & 73,170 & 11 & 33,754 & 5 & 45,089 & 7 \\
\hline 1995 & 77,653 & 12 & 17,725 & 3 & 403,894 & 64 & 63,067 & 10 & 26,407 & 4 & 41,348 & 7 \\
\hline 1996 & 78,969 & 13 & 16,960 & 3 & 388,905 & 64 & 68,373 & 11 & 15,268 & 3 & 39,385 & 6 \\
\hline 1997 & 82,078 & 16 & 15,664 & 3 & 381,540 & 64 & 68,597 & 12 & 7,697 & 1 & 38,554 & 6 \\
\hline 1998 & 87,569 & 15 & 14,041 & 2 & 365,862 & 63 & 67,786 & 12 & 9,239 & 2 & 35,607 & 6 \\
\hline
\end{tabular}

${ }^{1}$ Major AI organizations had a sampling controller or controller code of 1 through 99 and 101 through 222 as assigned by the National Association of Animal Breeders (Columbia, MO); marketing-only AI organizations had a code of 100 or $\geq 2000$. 
Table 12. Means of Holstein yield deviations by year of first calving and AI status ${ }^{1}$ of sire.

\begin{tabular}{|c|c|c|c|c|c|c|c|}
\hline \multirow[b]{2}{*}{$\begin{array}{l}\text { Yield } \\
\text { trait }\end{array}$} & \multirow[b]{2}{*}{ Year } & \multicolumn{2}{|c|}{ Progeny test } & \multicolumn{2}{|c|}{ AI proven } & \multirow{2}{*}{$\begin{array}{l}\text { Natural-service } \\
\text { proven, } \\
\text { AI marketed }\end{array}$} & \multirow{2}{*}{$\begin{array}{l}\text { Natural } \\
\text { service } \\
\text { use only }\end{array}$} \\
\hline & & Major AI & $\begin{array}{l}\text { Marketing- } \\
\text { only AI }\end{array}$ & Major AI & $\begin{array}{l}\text { Marketing- } \\
\text { only AI }\end{array}$ & & \\
\hline & & & & & $(\mathrm{kg})$ & & \\
\hline Milk & $\begin{array}{l}1984 \\
1986 \\
1988 \\
1990 \\
1992 \\
1994 \\
1996 \\
1998\end{array}$ & $\begin{array}{r}-1594 \\
-1357 \\
-1184 \\
-1007 \\
-813 \\
-597 \\
-382 \\
-60\end{array}$ & $\begin{array}{r}-1627 \\
-1420 \\
-1272 \\
-1079 \\
-881 \\
-650 \\
-430 \\
-144\end{array}$ & $\begin{array}{r}-1430 \\
-1247 \\
-1070 \\
-900 \\
-665 \\
-440 \\
-195 \\
139\end{array}$ & $\begin{array}{r}-1635 \\
-1485 \\
-1354 \\
-1096 \\
-795 \\
-533 \\
-338 \\
-60\end{array}$ & $\begin{array}{r}-1544 \\
-1446 \\
-1299 \\
-1103 \\
-799 \\
-508 \\
-335 \\
-120\end{array}$ & $\begin{array}{r}-1803 \\
-1620 \\
-1460 \\
-1270 \\
-1043 \\
-807 \\
-611 \\
-302\end{array}$ \\
\hline Fat & $\begin{array}{l}1984 \\
1986 \\
1988 \\
1990 \\
1992 \\
1994 \\
1996 \\
1998\end{array}$ & $\begin{array}{r}-54 \\
-46 \\
-40 \\
-33 \\
-23 \\
-16 \\
-9 \\
1\end{array}$ & $\begin{array}{r}-54 \\
-48 \\
-44 \\
-35 \\
-25 \\
-18 \\
-10 \\
-2\end{array}$ & $\begin{array}{r}-49 \\
-43 \\
-37 \\
-29 \\
-20 \\
-14 \\
-6 \\
3\end{array}$ & $\begin{array}{r}-54 \\
-50 \\
-45 \\
-34 \\
-23 \\
-15 \\
-10 \\
-1\end{array}$ & $\begin{array}{r}-54 \\
-49 \\
-43 \\
-33 \\
-20 \\
-17 \\
-8 \\
2\end{array}$ & $\begin{array}{r}-61 \\
-55 \\
-49 \\
-42 \\
-33 \\
-24 \\
-18 \\
-8\end{array}$ \\
\hline Protein & \begin{tabular}{l|l}
1984 & \\
1986 & \\
1988 & \\
1990 & \\
1992 & \\
1994 & \\
1996 & \\
1998 &
\end{tabular} & $\begin{array}{r}-44 \\
-39 \\
-35 \\
-30 \\
-23 \\
-16 \\
-9 \\
0\end{array}$ & $\begin{array}{r}-43 \\
-40 \\
-37 \\
-32 \\
-25 \\
-18 \\
-10 \\
-2\end{array}$ & $\begin{array}{r}-40 \\
-36 \\
-32 \\
-27 \\
-20 \\
-13 \\
-6 \\
3\end{array}$ & $\begin{array}{r}-44 \\
-43 \\
-39 \\
-32 \\
-23 \\
-15 \\
-9 \\
0\end{array}$ & $\begin{array}{r}-44 \\
-44 \\
-39 \\
-31 \\
-21 \\
-15 \\
-10 \\
0\end{array}$ & $\begin{array}{r}-49 \\
-45 \\
-41 \\
-36 \\
-30 \\
-23 \\
-16 \\
-8\end{array}$ \\
\hline
\end{tabular}

${ }^{1}$ Major AI organizations had a sampling controller or controller code of 1 through 99 and 101 through 222 as assigned by the National Association of Animal Breeders (Columbia, MO); marketing-only AI organizations had a code of 100 or $\geq 2000$.

between herd PT use and timeliness of daughter information. Since 1990, herds with the highest PT use (50 to 99 and 100\%) produced daughter lactation information 2.0 to 3.5 mo earlier than those with the lowest PT use (1 to $9 \%$ ).

Table 10 shows that the percentage of PT bulls returned to AI service by major AI organizations has declined since the mid 1960s, thus allowing selection intensity to increase. Percentage of Holstein PT bulls returned to AI service, as defined by a $50 \%$ increase in number of daughters after PT, declined from $44 \%$ for bulls with PT sampling near 1965 to $14 \%$ for bulls with PT entry near 1990. For other breeds, 19 to $23 \%$ of recent bulls returned to AI service. That percentage translates to one in seven bulls being returned to AI service for Holsteins and about one in four or five bulls for other breeds. If a return to AI service is defined as a $100 \%$ increase in number of daughters after PT, the change across time for PT bulls returned to AI service was from 31 to $12 \%$ for Holsteins. Current rate of return to AI service after PT is one in eight bulls for Holsteins and one in from five to eight bulls (12 to $20 \%$ ) for other breeds. As the number of additional daughters required after PT increased up to 1000 for alternative definitions of "returned to service" (not shown), the percentage of qualifying bulls was as low as one in 25 . The effect of varying the trait definition illustrates the need to define "returned to service" equitably when comparing selection intensity across breeds or countries. Increased sampling of bulls since the 1960s combined with increased selection intensity has permitted more rapid genetic progress for all breeds.

Table 11 shows percentages of Holstein daughters that contributed to genetic evaluations by year of first calving and AI status of their sires. For cows that first calved in 1998, percentage of daughters with lactation records used in USDA-DHIA genetic evaluations was $15 \%$ for PT bulls from major AI organizations, $2 \%$ for PT bulls from marketing-only AI organizations, $63 \%$ for AI-proven bulls from major AI organizations, $12 \%$ for AI-proven bulls from marketing-only organizations, $2 \%$ for NS-proven bulls marketed through AI, and $6 \%$ for bulls used only through NS. Percentage of contributing daughters sired by PT bulls from major AI organizations increased from $8 \%$ in 1984 to $15 \%$ in 1998, whereas percentage sired by NS bulls dropped from 12 to $6 \%$. Percentage of contributing daughters sired by AI-proven bulls from major AI organizations increased from $61 \%$ in 1984 to $69 \%$ in 1990 and then 
Table 13. Means of sire PTA of Holstein cows by year of first calving and AI status ${ }^{1}$ of sire.

\begin{tabular}{|c|c|c|c|c|c|c|c|}
\hline \multirow[b]{2}{*}{$\begin{array}{l}\text { Yield } \\
\text { trait }\end{array}$} & \multirow[b]{2}{*}{ Year } & \multicolumn{2}{|c|}{ Progeny test } & \multicolumn{2}{|c|}{ AI proven } & \multirow{2}{*}{$\begin{array}{l}\text { Natural-service } \\
\text { proven, } \\
\text { AI marketed }\end{array}$} & \multirow{2}{*}{$\begin{array}{l}\text { Natural } \\
\text { service } \\
\text { use only }\end{array}$} \\
\hline & & $\begin{array}{l}\text { Major } \\
\text { AI }\end{array}$ & $\begin{array}{l}\text { Marketing- } \\
\text { only AI }\end{array}$ & $\begin{array}{l}\text { Major } \\
\text { AI }\end{array}$ & $\begin{array}{l}\text { Marketing- } \\
\text { only AI }\end{array}$ & & \\
\hline Milk & $\begin{array}{l}1984 \\
1986 \\
1988 \\
1990 \\
1992 \\
1994 \\
1996 \\
1998\end{array}$ & $\begin{array}{r}-550 \\
-393 \\
-309 \\
-211 \\
-130 \\
-14 \\
96 \\
220\end{array}$ & $\begin{array}{r}-602 \\
-490 \\
-394 \\
-286 \\
-195 \\
-77 \\
51 \\
142\end{array}$ & $\begin{array}{r}-434 \\
-335 \\
-245 \\
-167 \\
-53 \\
69 \\
216 \\
348\end{array}$ & $\begin{array}{r}-608 \\
-550 \\
-505 \\
-318 \\
-132 \\
34 \\
95 \\
185\end{array}$ & $\begin{array}{r}-525 \\
-507 \\
-436 \\
-336 \\
-165 \\
34 \\
67 \\
79\end{array}$ & $\begin{array}{r}-750 \\
-646 \\
-568 \\
-466 \\
-355 \\
-233 \\
-125 \\
-20\end{array}$ \\
\hline Fat & $\begin{array}{l}1984 \\
1986 \\
1988 \\
1990 \\
1992 \\
1994 \\
1996 \\
1998\end{array}$ & $\begin{array}{r}-18 \\
-14 \\
-11 \\
-6 \\
0 \\
3 \\
5 \\
10\end{array}$ & $\begin{array}{r}-19 \\
-15 \\
-13 \\
-8 \\
-3 \\
1 \\
4 \\
8\end{array}$ & $\begin{array}{r}-15 \\
-12 \\
-9 \\
-5 \\
0 \\
2 \\
6 \\
9\end{array}$ & $\begin{array}{r}-20 \\
-18 \\
-15 \\
-8 \\
-1 \\
3 \\
3 \\
6\end{array}$ & $\begin{array}{r}-19 \\
-17 \\
-13 \\
-8 \\
0 \\
0 \\
5 \\
8\end{array}$ & $\begin{array}{r}-25 \\
-22 \\
-19 \\
-15 \\
-10 \\
-6 \\
-3 \\
0\end{array}$ \\
\hline Protein & $\begin{array}{l}1984 \\
1986 \\
1988 \\
1989 \\
1990 \\
1992 \\
1994 \\
1996 \\
1998\end{array}$ & $\begin{array}{r}-16 \\
-12 \\
-11 \\
-10 \\
-7 \\
-3 \\
1 \\
5 \\
9\end{array}$ & $\begin{array}{r}-19 \\
-15 \\
-12 \\
-11 \\
-9 \\
-5 \\
-1 \\
4 \\
6\end{array}$ & $\begin{array}{r}-13 \\
-11 \\
-9 \\
-7 \\
-5 \\
-2 \\
2 \\
5 \\
9\end{array}$ & $\begin{array}{r}-17 \\
-16 \\
-15 \\
-13 \\
-10 \\
-4 \\
1 \\
3 \\
6\end{array}$ & $\begin{array}{r}-17 \\
-18 \\
-15 \\
-13 \\
-10 \\
-2 \\
0 \\
2 \\
6\end{array}$ & $\begin{array}{r}-21 \\
-19 \\
-16 \\
-15 \\
-14 \\
-10 \\
-6 \\
-3 \\
0\end{array}$ \\
\hline
\end{tabular}

\footnotetext{
${ }^{1}$ Major AI organizations had a sampling controller or controller code of 1 through 99 and 101 through 222 as assigned by the National Association of Animal Breeders (Columbia, MO); marketing-only AI organizations had a code of 100 or $\geq 2000$.
}

declined to $63 \%$ in 1998 . Percentage of contributing daughters sired by AI-proven bulls from marketingonly AI organizations increased from 0 to $12 \%$. The increase in contribution from daughters of AI PT and AI-proven bulls over time was enhanced by a large reduction (19 to $2 \%$ ) in percentage of contributing daughters from NS-proven bulls marketed through AI, an increase in herds participating in AI sampling, and possibly by an increase in percentage of AI use. How well the percentages of daughters of bulls from various AI-status categories that were present in records usable for genetic evaluation reflect the percentages of those categories for cows and heifers bred or for calves born or raised is unknown. Nevertheless, the likelihood of a strong, positive relationship between AI status of sires represented by breedings, progeny births, and usable lactation records is great enough that trend in AI-status categories based on information from usable records also should reflect trend in AI use for the population.

Table 12 compares yield deviations (VanRaden and Wiggans, 1991) of Holstein cows for milk, fat, and protein by AI status of sire. The general increase in means over time reflects current genetic trend in the US popu- lation. From 1984 through 1998 (only even years shown), daughters of AI-proven bulls from major AI organizations annually produced 107 to $199 \mathrm{~kg}$ more milk and 2 to $5 \mathrm{~kg}$ more fat and protein than did PT daughters from those same organizations. For the same period, daughters of AI-proven bulls from marketing-only AI organizations have changed from an 82-kg inferiority (1988) compared with daughter yield of PT bulls from those organizations to a $117-\mathrm{kg}$ superiority (1994), most likely because of less intense selection among bulls returning to AI for the marketingonly AI organizations during the earlier years. Table 12 also shows the relative advantage in productivity of AI daughters compared with those from NS. Daughters of AI-proven bulls from major AI organizations (weighted by number of daughters) annually produced 367 to $441 \mathrm{~kg}$ more milk than daughters of NS bulls; the annual advantage was 10 to $13 \mathrm{~kg}$ for fat and 9 to $11 \mathrm{~kg}$ for protein. Daughters of bulls entering AI based on an NS evaluation likewise produced less than daughters of AI-proven bulls from major AI organizations: from 56 to $259 \mathrm{~kg}$ less milk, 0 to $6 \mathrm{~kg}$ less fat, and 1 to $8 \mathrm{~kg}$ less protein. With the milk pricing formula used in calculation of the USDA net merit index 
[\$.010 (PTA milk) + \$1.15 (PTA fat) $+\$ 2.55$ (PTA protein)] (VanRaden, 2000), the higher milk, fat, and protein yields translate into an advantage of $\$ 20$ to 39 per lactation for AI-proven over PT bulls for major AI organizations and an advantage of $\$ 89$ to 101 for AI-proven bulls from those organizations over NS bulls. The decision to breed a heifer or cow to an AIproven bull from a major AI organization rather than to an NS bull would have resulted in a gain of $\$ 89$ to 101 in value of milk produced annually by resulting offspring. Therefore, the continuing failure to choose AI bulls appears to be one of the greatest lost opportunities on the dairy farm. If percentage of NS use in the United States is $10 \%$, the lost income to US producers from using NS bulls projects to $\$ 86.4$ million annually ( $10 \%$ of 9.1 million cows times $\$ 95$ ). If the percentage of NS use is 20 or $30 \%$, the lost income is $\$ 173$ or 259 million annually.

Table 13 shows sire PTA for milk, fat, and protein of Holstein cows by AI status of sire (even years shown). Mean sire PTA are weighted according to bull use because means were calculated on a daughter basis. Usually the ranking of mean sire PTA among AI status categories was similar to that among yield deviations in Table 12. Advantages in genetic merit of AI-proven bulls compared with PT bulls from major AI organizations was $128 \mathrm{~kg}$ milk in 1998. Advantages for AIproven bulls compared with NS bulls (368 kg milk in 1998) were larger than those found by Powell and Norman (1989). Tables 12 and 13 show that yield deviations and sire PTA, respectively, for the six AI status categories are ranked consistently across time for all three yield traits with the proven bulls and PT bulls of major AI organizations highest and followed by proven bulls of minor AI organizations, breeder-proven bulls, and PT bulls of minor AI organizations. The PTA and yield deviations of NS daughters were the lowest for every year calculated. The PTA for PT bulls from major AI organizations and NS bulls were closer to those for AI-proven bulls from major AI organizations than were corresponding yield deviations. Statistical tests showed that mean yield PTA for Holstein PT bulls from major AI organizations differed $(P<0.05)$ by month of semen release only for protein. Bulls with semen released in the winter had a slightly higher PTA for protein than did bulls with semen released in the other months.

\section{CONCLUSIONS}

Age of PT bulls when semen was distributed by major AI organizations has changed little over time. Age of PT bulls from those organizations when daughters were born declined by 4.5 mo for Holsteins and Jerseys; age of PT bulls when daughters calved declined by 6 mo for Holsteins and 5.5 mo for Jerseys. An increasing number and percentage of herds are participating in PT programs (now over $60 \%$ of Holstein herds). Percentage of PT bulls returned to active service by major AI organizations has steadily declined, which has increased selection intensity and enhanced genetic improvement. Percentage of cows with records used in genetic evaluations and sired by bulls sampled through AI use has increased from $70 \%$ in 1984 to $92 \%$ in 1998. Some of that increase may have resulted from the use of PT bulls by producers in place of NS bulls. Percentage of cows with records used in genetic evaluations and sired by AI-proven bulls from major AI organizations has remained constant. The AI-proven bulls transmitted modest genetic superiority over PT bulls and had an extremely large advantage over NS bulls. More extensive use of AI could increase US producers income by millions of dollars annually.

\section{ACKNOWLEDGMENTS}

Assistance of S. M. Hubbard, J. C. Philpot, and A. $\mathrm{H}$. Sanders of AIPL with manuscript review is appreciated. Data utilized in the research were supplied to the AIPL national dairy database by US dairy cattle breed associations, AI organizations, and dairy records processing centers; contributions of personnel from those organizations are acknowledged. A special thanks is extended to W. Glaeser, formerly of Semex USA (Madison, WI), who provided identification numbers for bulls sampled in the United States by Semex USA and to the anonymous Journal of Dairy Science reviewers for their useful suggestions.

\section{REFERENCES}

Abdullah, J. M., and B. T. McDaniel. 2002. Proven and young Holstein bulls compared for daughter yields, productive life, somatic cell score, and inbreeding. J. Dairy Sci. 85:665-669.

Animal Improvement Programs Laboratory. 2001. Summary of November 2001 evaluations. Online. Available: ftp://aipl.arsusda. gov/pub/bulls/0111.evalrpt. Accessed Aug. 5, 2002.

Hinks, C. J. M. 1978. The use of centralized breeding schemes in dairy cattle improvement. Anim. Breed. Abstr. 46:291-297.

King, G. J., and B. T. McDaniel. 1974. Milk and fat differences for grade cows sired by artificial and natural insemination. J. Dairy Sci. 57:562-566.

McDaniel, B. T., and W. E. Bell. 1992. Experimental comparison of systems of selecting Holstein bulls. J. Dairy Sci. 75(Suppl. 1):150. (Abstr.)

McDaniel, B. T., and G. J. King. 1974. Milk and fat differences for registered cows sired by artificial and natural insemination. J. Dairy Sci. 57:112-120.

Meinert, T. R., and R. E. Pearson. 1992. Stability of evaluations of bulls sampled by artificial insemination and other organizations. J. Dairy Sci. 75:564-571.

Meinert, T. R., R. E. Pearson, and R. S. Hoyt. 1992. Estimates of genetic trend in an artificial insemination progeny test program 
and their association with herd characteristics. J. Dairy Sci. 75:2254-2264.

Miller, P. D. 1981. Artificial insemination organizations. J. Dairy Sci. 64:1283-1287.

National Association of Animal Breeders. 2001. Cross reference participants. NAAB Electronic Resource Guide. Online. Available: http://www.naab-css.org/db/xrefpart.html. Accessed Dec. 28, 2001.

Nicholas, F. W., and C. Smith. 1983. Increased rates of genetic change in dairy cattle by embryo transfer and splitting. Anim. Prod. 36:341-353.

Norman, H. D., and R. L. Powell. 1986. Pedigree selection of dairy bulls in the United States and resultant progeny tests. Proc. 3rd World Congr. Genet. Appl. Livest. Prod. IX:196-201.

Norman, H. D., and R. L. Powell. 1992. Genetic change attained and possible. Pages 59-66 in Large Dairy Herd Management. Am. Dairy Sci. Assoc., Champaign, IL.

Norman, H. D., and R. L. Powell. 1999. Dairy cows of high genetic merit for yields of milk, fat, and protein-a review. Asian-Aus. J. Anim. Sci. 12:1316-1323.
Norman, H. D., R. L. Powell, and J. R. Wright. 1985. Changes of evaluation for natural-service sampled bulls brought into artificial insemination. J. Dairy Sci. 68:1513-1522.

Norman, H. D., R. L. Powell, J. R. Wright, and C. G. Sattler. 2001. Overview of progeny-test programs of artificial-insemination organizations in the United States. J. Dairy Sci. 84:1899-1912.

Powell, R. L., and H. D. Norman. 1989. Genetic differences among categories of service sires. J. Dairy Sci. 72:1842-1853.

Sattler, C. G. 1990. AI sires will be labeled by sampling method. Hoard's Dairyman 135:600.

Smith, C. 1988. Genetic improvement of livestock, using nucleus breeding units. World Anim. Rev. 65:2-10.

VanRaden, P. M. 2000. Net merit as a measure of lifetime profit. AIPL Res. Rep. NM\$1(11-00). Online. Available: http://aipl.arsusda.gov/docs/nm2000.html. Accessed Aug. 12, 2002.

VanRaden, P. M., and G. R. Wiggans. 1991. Derivation, calculation, and use of national animal model information. J. Dairy Sci. 74:2737-2746.

Weigel, D. J., B. G. Cassell, and R. E. Pearson. 1995. Relative genetic merit and effectiveness of selection of young sires for artificial insemination. J. Dairy Sci. 78:2481-2485. 